\title{
Effect of short-term elevations in plasma cortisol concentration on LH secretion in prepubertal gilts
}

\author{
G. P. Pearce, A. M. Paterson* and P. E. Hughes $\dagger \ddagger$ \\ Animal Science Group, School of Agriculture, University of Western Australia, Nedlands, Western \\ Australia 6009, Australia; *Animal Production Division, Department of Agriculture, Baron-Hay \\ Court, South Perth, Western Australia 6151, Australia; and $\dagger$ Muresk Institute of Agriculture, \\ Northam, Western Australia 6401, Australia
}

\begin{abstract}
Summary. Prepubertal gilts were fitted with jugular vein and carotid artery catheters at 148 days of age. At 160 days of age the 24 gilts were allocated to treatment in a $2 \times 2$ factorial design involving intra-carotid infusion of cortisol ( $10 \mathrm{mg}$ in $40 \mathrm{ml}$ saline) or saline alone with or without i.v. injection of $5 \mu \mathrm{g}$ synthetic GnRH midway through the $1 \mathrm{~h}$ infusion. Plasma cortisol concentrations were elevated in gilts infused with cortisol $(P<0.05)$. The $\mathrm{LH}$ response to exogenous $\mathrm{GnRH}$ was reduced by cortisol infusion. Treated gilts released less LH $(P<0.001)$ and had a lower mean LH peak $(P<0.01)$ than did control gilts but the timing of the induced LH peak was not affected. In the absence of an exogenous GnRH challenge, cortisol infusion increased the endogenous secretion of $\mathrm{LH}(P<0.01)$. These results suggest that acute elevations in plasma cortisol concentration may be involved in mediating changes in pituitary responsiveness and the secretion of LH in the peripubertal gilt.
\end{abstract}

Keywords: prepubertal gilts; elevated cortisol; LH secretion

\section{Introduction}

The most effective methods available to stimulate the attainment of precocious puberty in the gilt are contact with a mature boar and management practices such as mixing, relocation and transportation of gilts. All of these methods of puberty stimulation induce an acute stress response in the gilt, the most reliable indicator of which is a rapid elevation in plasma cortisol concentrations (Dantzer \& Mormede, 1981). This response has been demonstrated in gilts during physical contact with boars (Pearce \& Hughes, 1987) and during transportation (Spencer, 1980). Boar-induced precocious puberty in the gilt is delayed by adrenalectomy (Killian et al., 1987) or pharmacological inhibition of adrenal function (Wodzicka-Tomaszewska et al., 1985) and enhanced by the additional exposure to the stress of transport (Wodzicka-Tomaszewska et al., 1985) or relocation (Eastham \& Cole, 1987). The widely accepted 'gonadostat' hypothesis for the endocrine control of puberty (Ramirez \& McCann, 1963) requires a change in the sensitivity of the hypothalamic-pituitary axis to steroid feedback in the peripubertal period. The acute stress response to boar exposure and/or transport may be involved in mediating these changes in feedback in the gilt.

Therefore the present study investigated the influence of acutely elevated concentrations of plasma cortisol on the endogenous and GnRH-induced release of LH from the pituitary gland of prepubertal gilts.

¡Present address: School of Agriculture and Forestry, University of Melbourne, Parkville, Victoria 3052, Australia. 


\section{Materials and Methods}

Animals. Prepubertal Large White $\times$ Landrace crossbred gilts from 6 litters were housed in metabolism crates in two groups of 12 gilts at a mean age of 148 days (range 142-153 days) and a mean liveweight of $73.0 \mathrm{~kg}$ (range $65.082 .0 \mathrm{~kg}$ ). The gilts were fitted with urinary catheters (Foley 2-way) and allowed 5-9 days to acclimatize to the crates. Each gilt was then surgically implanted with indwelling jugular vein and carotid artery catheters (Silastic medical grade tubing, i.d. $1.57 \mathrm{~mm}$, o.d. $3.17 \mathrm{~mm}$; Dow Corning Corp., Midland MI, U.S.A.) under halothaneinduced anaesthesia.

Immediately after catheterization the gilts were returned to their crates and allowed a further 4-7 days to recover from surgery before treatment began at a mean age of 160 days. Gilts were slaughtered soon after treatment and their reproductive tracts were examined to assess reproductive status.

Treatment procedures. Six gilts were allocated according to litter across each of the following treatment groups: Group 1: infusion of $40 \mathrm{ml}$ saline/ethanol solution (10\% ethanol); Group 2: infusion of $40 \mathrm{ml}$ saline/ethanol plus injection of $5 \mu \mathrm{g} \mathrm{GnRH}$; Group 3: infusion of $40 \mathrm{ml}$ saline/ethanol containing $10 \mathrm{mg}$ cortisol; and Group 4: infusion of $40 \mathrm{ml}$ saline/ethanol containing $10 \mathrm{mg}$ cortisol plus injection of $5 \mu \mathrm{g} \mathrm{GnRH}$. Saline $(8 \cdot 9 \mathrm{~g} \mathrm{NaCl} / 1)$ or cortisol (Sigma Chemical Co., St Louis, MO, U.S.A.) was infused by connecting a previously calibrated syringe infusion pump (Unita I, B. Braun, Melsungen, A.G., West Germany) to the carotid artery catheter of the gilt. The infusion lasted $1 \mathrm{~h}$ from $15: 17 \mathrm{~h}$ until $16: 17 \mathrm{~h}$ on the day of treatment. Halfway through the infusion Groups 2 and 4 were injected with $5 \mu \mathrm{g}$ synthetic gonadotrophin-releasing hormone $(\mathrm{GnRH})$ in $1 \mathrm{ml}$ saline (Gonadorelin as Fertygal: Intervet (Australia) Pty Ltd, Artarman, NSW, Australia) via the jugular catheter which was immediately flushed with $3 \mathrm{ml}$ saline. This analogue of $\mathrm{GnRH}$ is approximately $10 \%$ more potent than natural $\mathrm{GnRH}$.

Hormone assays. Plasma concentrations of $\mathrm{LH}$ were determined using a double-antibody radioimmunoassay technique previously reported and validated by Niswender et al. (1970). Purified pig LH (LER-2-206) was iodinated with ${ }^{125}$ I (New England Nuclearchemical Products, Boston, MA, U.S.A.) using the chloramine-T procedure and was used for the preparation of standards in the range of 0.125 to $32 \mathrm{ng} / \mathrm{ml}$. After dilution of anti-pig LH serum (1:12 000, GDN No. 566), $100 \mu \mathrm{l}$ of this serum were added to each assay tube containing $100 \mu l$ unknown plasma and $300 \mu l$ phosphate-buffered saline. Samples were incubated at $4^{\circ} \mathrm{C}$ for $24 \mathrm{~h}$ before $100 \mu \mathrm{l}^{125} \mathrm{I}$-labelled pig LH (10000 c.p.m.) were added and incubated for a further $72 \mathrm{~h}$ at $4^{\circ} \mathrm{C}$. Anti-rabbit gamma globulin $(200 \mu \mathrm{l})$ was then added and the samples were incubated for a further $24 \mathrm{~h}$ at $4^{\circ} \mathrm{C}$. Then $1 \mathrm{ml}$ phosphate-buffered saline was added and the samples were centrifuged at $3000 \mathrm{~g}$ for $30 \mathrm{~min}$ before the supernatant was aspirated, $250 \mu \mathrm{l} 0 \cdot 1 \mathrm{~N}-\mathrm{NaOH}$ were added and the radioactivity was determined in an automatic gamma counter.

The limit of detection was $0.25 \mathrm{ng} / \mathrm{ml}$ and samples containing less than $0.25 \mathrm{ng} / \mathrm{ml}$ were assigned this value for analysis. Standard plasma samples containing high $(5 \mathrm{ng} / \mathrm{ml})$ or low $(1.5 \mathrm{ng} / \mathrm{ml})$ concentrations of LH were included in the assays and used to estimate intra- and inter-coefficients of variation, which were 9.8 and $11.6 \%$ respectively.

Plasma concentrations of cortisol were determined by a competitive binding assay previously described in detail by Barnett et al. (1981). The limit of detection was $0.15 \mathrm{ng} / \mathrm{ml}$ and the intra- and inter-assay coefficients of variation were 4.6 and $8.6 \%$ respectively.

Statistical analysis. Plasma patterns of cortisol and LH were analysed by measuring total areas under the hormone curves (ng.min $/ \mathrm{ml}$ ) and calculating mean levels before and after GnRH injection. This was done before, during and after cortisol infusion and over all the samples taken between 14:00 and 18:00 h. Treatment effects were assessed using factorial analysis of variance procedures and paired Student's $t$ tests.

\section{Results}

The mean plasma concentrations of total cortisol and LH for the four treatment groups are shown in Fig. 1. During the 1-h infusion, gilts in Groups 3 and 4 had higher plasma cortisol concentrations than did gilts in Groups 1 and $2(P<0.05)$ and their plasma cortisol concentrations did not return to baseline levels until $88 \mathrm{~min}$ after the infusion finished. The mean total area under the cortisol curve was smaller in Group 4 than in Group 3 gilts $\left(1.2 \times 10^{5} v s 1.5 \times 10^{5} \mathrm{ng} . \mathrm{min} / \mathrm{ml}, P<0.01\right)$ but this was due to individual variation among gilts in the peak level of cortisol attained and not to the GnRH injection.

The mean areas under the LH curve before and after GnRH injection in Groups 2 and 4 and equivalent times in Groups 1 and 3 are shown in Fig. 2. There was no difference in LH secretion among treatments before the GnRH injections. More LH was released in response to GnRH in gilts in Group 2 (saline) than gilts in Group 4 (cortisol) $(P<0.001)$. The mean LH peak concentration in response to GnRH was also higher in saline-infused gilts than cortisol-infused gilts 


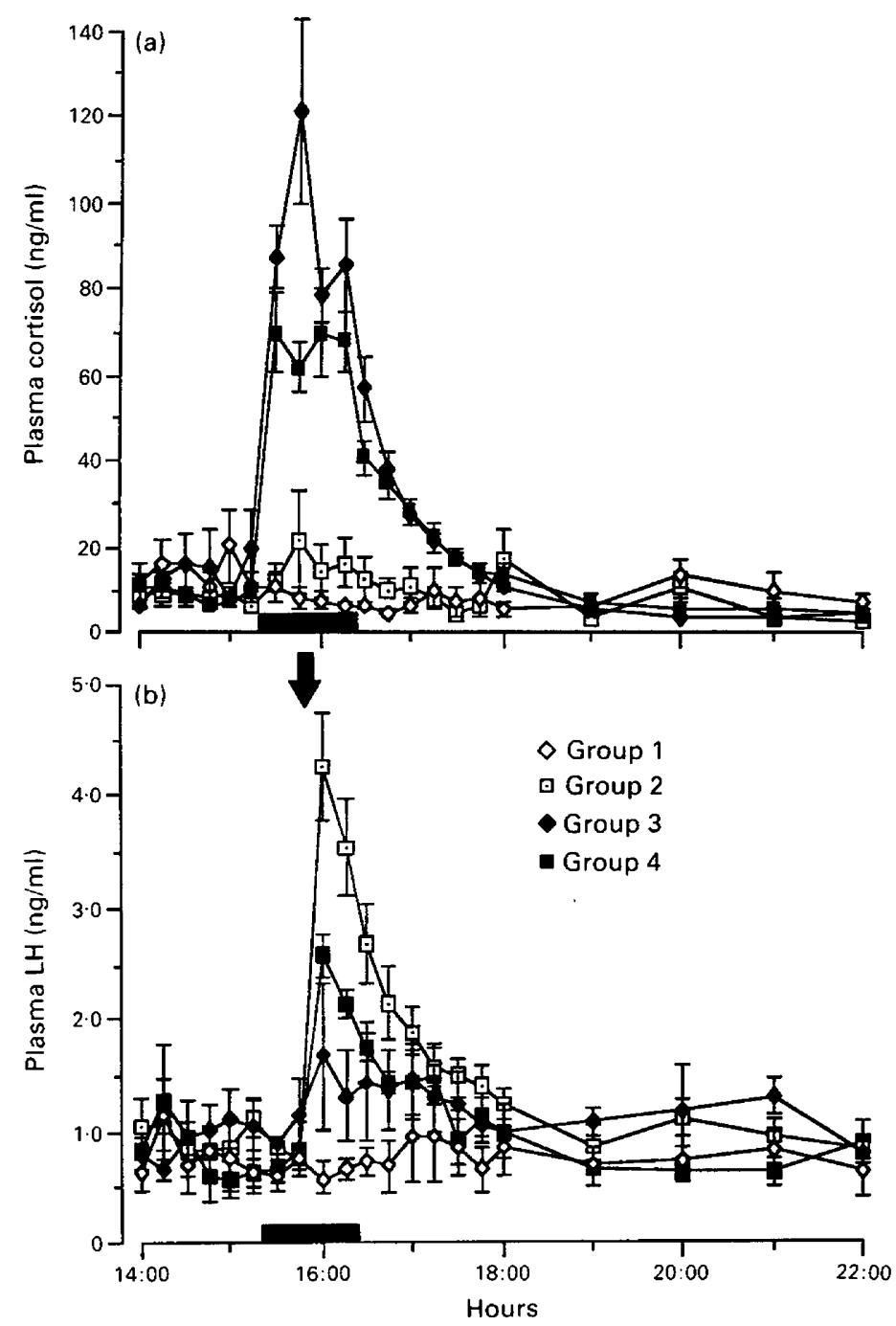

Fig. 1. The effect of treatment on (a) cortisol and (b) LH concentrations (mean \pm s.e.m.) in plasma of prepubertal gilts treated with saline (Group 1), saline + GnRH (Group 2), cortisol (Group 3) or cortisol + GnRH (Group 4). Horizontal bar = period of infusion; arrow = time of GnRH injection.

$(4.2 \pm 0.5$ vs $2.6 \pm 0.2 \mathrm{ng} / \mathrm{ml}, P<0.01)$ but the interval from $\mathrm{GnRH}$ injection to the $\mathrm{LH}$ peak was not affected by treatment (Fig. 1). In gilts infused with saline, injection of GnRH significantly increased the total secretion of $\operatorname{LH}(P<0.01)$. However, among the gilts infused with cortisol there was no significant difference in $\mathrm{LH}$ release due to GnRH injection (Fig. 2) because the gilts which did not receive GnRH also exhibited a significant increase of LH secretion above baseline levels during the infusion. In fact the gilts infused with cortisol alone secreted more $\mathrm{LH}$ than did gilts infused with saline alone $(P<0 \cdot 01$, Fig. 2$)$.

All gilts had small undeveloped uteri and ovaries containing only small follicles $(<3 \mathrm{~mm}$ in diameter) at slaughter. 


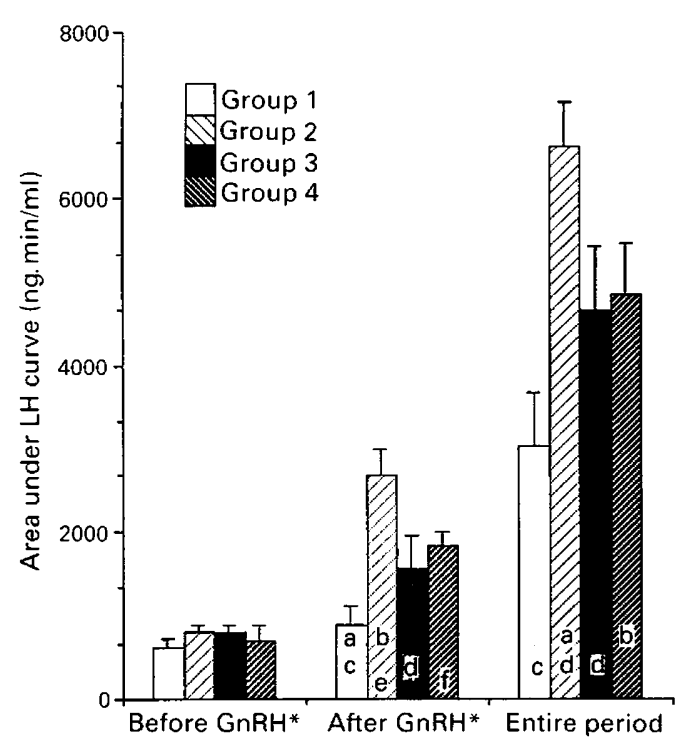

Fig. 2. The effects on mean \pm s.e.m. area under the LH curve of treatment of prepubertal gilts with saline (Group 1), saline + GnRH (Group 2), cortisol (Group 3) or cortisol + GnRH (Group 4). *Or equivalent time in non-GnRH-injected gilts. a $v s$ b: values are significantly different $(P<0.001)$; c vs d: values are significantly different $(P<0.01)$; e $v s$ f: values are significantly different $(P<0 \cdot 05)$.

\section{Discussion}

Acute elevations of plasma cortisol achieved by intra-carotid infusion of cortisol in prepubertal gilts significantly reduced the responsiveness of the pituitary gland to a single injection of synthetic GnRH. Although Fonda et al. (1984) observed no significant effect of exogenous cortisol or ACTH on GnRH-induced secretion of $\mathrm{LH}$ in intact prepubertal gilts, they used a very large dose of $400 \mu \mathrm{g}$ GnRH which may have over-ridden any changes in pituitary responsiveness. The dose of GnRH used in the present study induced an LH release within the normal physiological range for gilts reaching puberty (Esbenshade et al., 1982). The concentrations of plasma cortisol obtained as a result of the infusion were also within the range of levels reported for gilts approaching puberty (Diekman \& Trout, 1984) although they were higher than levels observed in gilts exposed to boars (Pearce \& Hughes, 1987). The effects of treatments observed in the present study therefore probably reflect physiological rather than pharmacological responses.

Work with female rats (Baldwin \& Sawyer, 1974) and male sheep (Matteri et al., 1984) has shown that elevated plasma corticosteroid concentrations can reduce pituitary responsiveness to exogenous GnRH. The present study shows that this effect also operates in the female pig and may explain why elevations in plasma cortisol can depress the preovulatory surge of LH in mature gilts (Barb et al., 1982) and why ACTH suppresses the increase in LH in prepubertal gilts after ovariectomy only when the adrenal glands are present (Fonda et al., 1984).

Liptrap \& Raeside (1983) reported that short-term cortisol infusions enhanced the pituitary responsiveness of mature boars to exogenous GnRH. However, high levels of plasma corticosteroids induced by exogenous ACTH have been reported to depress LH secretion in boars (Liptrap \& Raeside, 1975; Pitzel et al., 1984). It therefore appears that the effect of corticosteroids on pituitary responsiveness to GnRH may vary with the method used to increase plasma 
corticosteroids, the duration of the increase and also with the sex and physiological status of the animals.

In the absence of exogenous $\mathrm{GnRH}$, $\mathrm{LH}$ secretion was greater in cortisol-infused than in salineinfused gilts. This may simply be due to random occurrence of LH pulses in individual animals or it may represent a real increase in the endogenous release of $\mathrm{LH}$ induced by cortisol. Evidence to support the latter suggestion has been obtained by $\mathrm{Li}$ (1987) who found that incubation of pig pituitary cells with cortisol increased their basal secretion of $\mathrm{LH}$ but decreased their $\mathrm{LH}$ release in response to exogenous GnRH. This finding is in complete agreement with our results in vivo and suggests that corticosteroids may play a complex role in regulating $\mathrm{LH}$ secretion in female pigs.

Lutz et al. (1984) reported that endogenous serum LH increased immediately before puberty in gilts and this was suggested to be a consequence of a decrease in the sensitivity to negative oestrogen feedback on gonadotrophin secretion which is consistent with the 'gonadostat' hypothesis of puberty attainment (Ramirez \& McCann, 1963). However, Lutz et al. (1984) also reported that initial changes in serum LH secretion in the peripubertal gilt occurred while serum oestrogen concentrations were constant and work with women (Conte et al., 1981) and ewes (Foster \& Ryan, 1979) has shown that the peripubertal rise in LH is also independent of gonadal steroids. Furthermore, it has been proposed from work with rats that the change in the sensitivity of the gonadostat occurs after, not before, the pubertal rise in LH (Andrews et al., 1981). These studies suggest that other factors may also be involved in controlling prepubertal gonadotrophin secretion. Our observations that acute elevations of plasma cortisol altered endogenous LH secretion suggests that plasma cortisol concentrations are such a factor in the prepubertal gilt. The physiological significance of the acute elevation of plasma cortisol known to occur in the gilt during exposure to mature boars (Pearce \& Hughes, 1987) may therefore be to increase basal LH secretion at the time of puberty onset.

We thank the Pig Research Council of Australia for supporting this study; Mrs A. N. Pearce and $\mathrm{Mr} \mathrm{H}$. Payne for technical assistance; $\mathrm{Dr}$ J. L. Barnett for carrying out the plasma corticosteroid analysis; and Dr G. B. Martin for his helpful comments on the manuscript.

\section{References}

Andrews, W.W., Advis, J.P. \& Ojeda, S.R. (1981) The maturation of estradiol-negative feedback in female rats: Evidence that the resetting of the hypothalamic 'gonadostat' does not precede the first preovulatory surge of gonadotrophins. Endocrinology 109, 2022-2031.

Barb, C.R., Kraeling, R.R., Rampacek, G.B., Fonda, E.S. \& Kiser, T.E. (1982) Inhibition of ovulation and $\mathbf{L H}$ secretion in the gilt after treatment with ACTH or hydrocortisone. J. Reprod. Fert. 64, 85-92.

Baldwin, D.M. \& Sawyer, C.H. (1974) Effects of dexamethasone on $\mathrm{LH}$ release and ovulation in the cyclic rat. Endocrinology 94, 1397-1403.

Barnett, J.L., Cronin, G.M. \& Winfield, C.G. (1981) The effect of individual and group penning of pigs on total and free plasma corticosteroid binding capacity. Gen. comp. Endocr. 44, 219-225.

Conte, F.A., Grumbach, M.M., Kaplan, S.L. \& Reiter, E.O. (1981) Correlation of LRF-induced LH and FSH release from infancy to 19 years with the changing pattern of gonadotrophin secretion in agonadal patients. J. clin. Endocr. Metab. 50, 1163.

Dantzer, R. \& Mormede, P. (1981) Can physiological criteria be used to assess welfare in pigs? Curr. Topics Vet. Med. Anim. Sci. 11, 53-73.

Diekman, M.A. \& Trout, W.E. (1984) Serum profiles of progesterone, LH, FSH and prolactin immediately preceding induced puberty in gilts. J. Anim. Sci. 58, $1262-1270$.

Eastham, P.R. \& Cole, D.J.A. (1987) Reproduction in the gilt 7. Exposure of young gilts to the same mature boar and relocation: effects on the attainment of puberty. Anim. Prod. 44, 435-442.

Esbenshade, K.L., Paterson, A.M., Cantley, T.C. \& Day, B.N. (1982) Changes in plasma hormone concentrations associated with the onset of puberty in the gilt. J. Anim. Sci. 54, 320-324.

Fonda, E.S., Rampecek, G.B. \& Kraeling, R.R. (1984) The effect of adrenocorticotropin or hydrocortisone on serum luteinizing hormone concentrations after adrenalectomy and/or ovariectomy in the prepubertal gilt. Endocrinology 114, 268-273.

Foster, D.L. \& Ryan, K.D. (1979) Endocrine mechanisms governing transition into adulthood: a marked decrease in inhibitory feedback action of luteinizing hormone in the lamb during puberty. Endocrinology 105, 896-904.

Killian, D.B., Keisling, D.O., Wulf, F.P. \& Stewart, 
A.N.V. (1987) Effects of adrenalectomy and glucocorticoids on puberty in gilts reared in confinement. J. Anim. Sci. 64, 231-236.

Li, P.S. (1987) The effects of cortisol and ACTH on LH secretion by pig pituitary cells in vitro. Biol. Reprod. 36, 119 , Abstr.

Liptrap, R.M. \& Raeside, J.I. (1975) Increase in plasma testosterone concentration after injection of adrenocorticotrophin into the mature boar. J. Endocr. 66, 123-131.

Liptrap, R.M. \& Raeside, J.I. (1983) Effect of cortisol on the response to gonadotrophin releasing hormone in the boar. J. Endocr. 97, 75-81.

Lutz, J.B., Rampacek, G.B., Kraeling, R.R. \& Pinkert, C.A. (1984) Serum luteinizing hormone and estrogen profiles before puberty in the gilt. J. Anim. Sci. 58, 686-691.

Matteri, R.L., Watson, J.G. \& Moberg, G.P. (1984) Stress or acute adrenocorticotrophin treatment suppresses LHRH-induced release in the ram. J. Reprod. Fert. 72, 385-393.

Niswender, G.D., Reichert, L.E. \& Zimmerman, D.R. (1970) Radioimmunoassay of serum levels of lutei- nizing hormone throughout the estrous cycle in the pig. Endocrinology 87, $576-580$.

Pitzel, L., Hartig, A., Fenske, M., Holtz, W. \& Konig, A. (1984) The effect of long-acting ACTH on plasma corticosteroids, testosterone and LH levels in the male pig. Expl. clin. Endocrinol. 83, 14-20.

Pearce, G.P. \& Hughes, P.E. (1987) The influence of male contact on plasma cortisol concentrations in the prepubertal gilt. J. Reprod. Fert. 80, 417-424.

Ramirez, V.D. \& McCann, S.M. (1963) Comparison of the regulation of luteinizing hormone $(\mathrm{LH})$ in immature and adult rats. Endocrinology 72, 452.

Spencer, G.S.G. (1980) Relationship between plasma somatomedin activity and levels of cortisol and freefatty acids following stress in pigs. J. Endocr. 84, 109-114.

Wodzicka-Tomaszewska, M., Martinat-Botte, F., Prunier, A. \& Signoret, J.P. (1985) Effets respectifs de la mise en presence du mâle et du stress sur le déclenchment de la puberté de la jeune truie. Essais preliminaires. Journées Rech. porc en France 17, 139-146.

Received 28 September 1987 